University of Nebraska - Lincoln

DigitalCommons@University of Nebraska - Lincoln

Other Publications in Zoonotics and Wildlife

Disease

Wildlife Disease and Zoonotics

2003

\title{
Properties of a disease-specific prion probe
}

\author{
Guy Gorochov \\ Immunologie A, Hôpital Pitié-Salpêtrière \\ Jean-Phillippe Deslys \\ Groupe d'Innovation Diagnostique et Thérapeutique sur les Infections à Prions \\ Eustache Paramithiotis \\ Caprion Pharmaceuticals \\ Marc Pinard \\ Caprion Pharmaceuticals \\ Trebor Lawton \\ INDEXX Laboratories
}

See next page for additional authors

Follow this and additional works at: https://digitalcommons.unl.edu/zoonoticspub

Part of the Veterinary Infectious Diseases Commons

Gorochov, Guy; Deslys, Jean-Phillippe; Paramithiotis, Eustache; Pinard, Marc; Lawton, Trebor; LaBoissiere, Sylvie; Leathers, Valerie L.; Zou, Wen-Quan; Estey, Lisa A.; Lamontagne, Julie; Lehto, Marty T.; Kondejewski, Leslie H.; Francoeur, Gregory P.; Paoadopoulos, Maria; Haghighat, Ashkan; Spatz, Stephen J.; Head, Mark; Will, Robert; Ironside, James; O'Rourke, Katherine I.; Tonelli, Quentin; Ledebur, Harry C.; Chakrabartty, Avi; and Cashman, Neil R., "Properties of a disease-specific prion probe" (2003). Other Publications in Zoonotics and Wildlife Disease. 149.

https://digitalcommons.unl.edu/zoonoticspub/149

This Article is brought to you for free and open access by the Wildlife Disease and Zoonotics at DigitalCommons@University of Nebraska - Lincoln. It has been accepted for inclusion in Other Publications in Zoonotics and Wildlife Disease by an authorized administrator of DigitalCommons@University of Nebraska - Lincoln. 


\section{Authors}

Guy Gorochov, Jean-Phillippe Deslys, Eustache Paramithiotis, Marc Pinard, Trebor Lawton, Sylvie LaBoissiere, Valerie L. Leathers, Wen-Quan Zou, Lisa A. Estey, Julie Lamontagne, Marty T. Lehto, Leslie H. Kondejewski, Gregory P. Francoeur, Maria Paoadopoulos, Ashkan Haghighat, Stephen J. Spatz, Mark Head, Robert Will, James Ironside, Katherine I. O'Rourke, Quentin Tonelli, Harry C. Ledebur, Avi Chakrabartty, and Neil R. Cashman 


\section{Properties of a disease-specific prion probe}

\section{To the editor:}

In a recently published article ${ }^{1}$, Paramithiotis et al. describe antibodies specific for the prion Tyr-Tyr-Arg (YYR) repeat motif. These antibodies interact with the pathological isoform of the prion protein $\left(\mathrm{PrP}^{\mathrm{Sc}}\right)$, but not with the normal cellular isoform $(\mathrm{PrP})$. Because of this restricted specificity, they suggest that YYR-specific antibodies could be useful for the diagnosis and treatment of prion diseases (Fig. 1). The monoclonal antibodies, all of the IgM isotype, were produced by immunizing mice with a synthetic peptide (CYYRRYYRYY). When coupled to magnetic beads, these YYR-specific antibodies immunoprecipitate $\mathrm{PrP}^{\mathrm{Sc}}$ much more efficiently than $\operatorname{PrP}^{\mathrm{C}}$. Notably, the Paramithiotis study did not rely on antibodies to YYR for specific detection of PrP. Their immunoblots were not ultimately probed with $\mathrm{Pr}^{\mathrm{Sc}}$-specific antibodies, but rather with 'regular' antibodies. The latter can detect $\operatorname{PrP}$ (but do not distinguish between $\operatorname{PrP}^{S c}$ and $\operatorname{PrP}^{C}$ ) in a precipitate that could include any protein containing solvent-accessible tyrosine and arginine residues.

This report is notably similar to that of Korth et al. ${ }^{2}$, who described a Prp ${ }^{\mathrm{Sc}}$-specific IgM (designated 15B3) after immunizing with full-length recombinant bovine PrP. The 15B3 epitope consists of three separate, linear segments of PrP (15B3-1, 15B3-2 and 15B3-3). The YYR epitope (bold) identified by Paramithiotis et al. is included in or located near two of the 15B3 segments (underlined): GSDYEDRYYR (15B3-1) and YYRPVDQYS (15B3-2). Thus, these two independent studies relying on the same method of immunoprecipitation have identified similar IgM antibodies interacting with the same region on $\operatorname{PrP}$, and possibly with the same YYR motifs.

The new reagents described could put an end to the quest for a $\mathrm{PrP}^{\mathrm{Sc}}$-specific antibody. Because the authors envision therapeutic use of the described antibodies, however, it seems appropriate to emphasize that YYR-specific antibodies could interact with any protein with tyrosine and arginine residues on its surface. In regard to $\mathrm{PrP}^{\mathrm{Sc}}$ detection, it should be noted that no diagnostic application of $15 \mathrm{~B} 3$ has been reported since the report of Korth et al. was published in in 1997. The availability of new diagnostic tests sensitive enough to ensure the protection of public health is an important issue $e^{3}$. For the design of such tests, there remains the choice between high-affinity antibodies that recognize both $\operatorname{PrP}^{\mathrm{Sc}}$ and

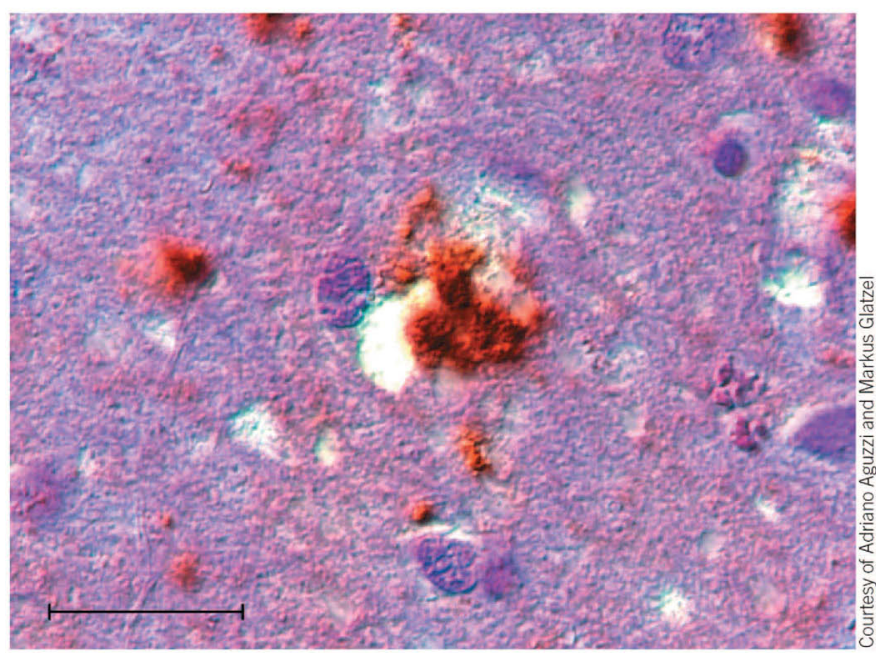

Figure 1 Conversion of the normal form of the prion protein $\left(\mathrm{PrPC}^{\mathrm{C}}\right)$ to the pathogenic form (PrPSc) produces protein aggregates such as these. Scale bar, $20 \mu \mathrm{m}$.

$\mathrm{PrP}^{\mathrm{C}}$ but require prior elimination of $\mathrm{PrP}^{\mathrm{C}}$, and lower-affinity but $\mathrm{PrP}^{\mathrm{Sc}}$-specific antibodies.

COMPETING INTERESTS STATEMENT

The authors declare competing financial interests (see the Nature Medicine website for details).

Guy Gorochov ${ }^{1}$ \& Jean-Philippe Deslys ${ }^{2}$ ${ }^{1}$ INSERM U543, Immunologie A, Hôpital PitiéSalpêtrière, 75013 Paris, France.

${ }^{2}$ CEA/DSV/DRM, Groupe d'Innovation Diagnostique et Thérapeutique sur les Infections à Prions, CEA FAR, 18 Route du Panorama, BP6 92265 Fontenay-aux-Roses cedex, France. e-mail:guy.gorochov@psl.ap-hop-paris.fr

1. Paramithiotis, E. et al. Nat. Med. 9, 893-899 (2003)

2. Korth, C. et al. Nature 390, 74-77 (1997).

3. Deslys, J.P. et al. Nature 409, 476-478 (2001).

\section{Paramithiotis et al. reply:}

We did indeed use 'regular' PrP-specific antibodies for the immunoblotting and ELISA detection of $\mathrm{PrP}^{\mathrm{Sc}}$ captured by our YYR-specific antibodies. However, we were also able to detect native $\mathrm{PrPSc}^{\mathrm{Sc}}$ at the surface of scrapie-infected sheep dendritic cells using direct immunostaining protocols ${ }^{1}$. In addition, because YYR-specific antibodies do not react with brain homogenate by immunoblot, and do not seem to possess significant surface reactivity on normal dissociated neurons or lymphoid cells, this epitope is apparently rare in the structural proteome.

Gorochov and Deslys perceive a parallel between our hypothesis-driven discovery of the YYR epitope $e^{1}$ and a previous report of a single putatively $\mathrm{PrP}^{\mathrm{Sc}}$-specific monoclonal antibody, 15B3 (ref. 2). We used biophysical methods to define the minimal peptide epitope YYR, then used YYR to immunize wildtype animals. This generated polyclonal antibodies and more than $40 \mathrm{PrP}^{\mathrm{Sc}}$-selective monoclonal antibodies (including three IgGs). The 15B3 monoclonal antibody, in contrast, was raised in $\mathrm{Prnp}^{-1-}$ mice immunized with recombinant bovine PrP. The 15B3 epitope was defined by reactivity to a 'gridded array' of bovine PrP 13-mer peptides staggered in register on a cellulose membrane $^{2}$. Using this method, the $15 \mathrm{~B} 3$ 


\section{CORRESPONDENCE}

epitope was interpreted to be discontinuous, comprising three segments that occupy $\sim 20 \%$ of the sequence of the $\operatorname{Pr} P$ structured domain. If YYR were the 15B3 epitope, this sequence would have been centrally located in all three segments; however, only one segment contained the complete YYR motif at the extreme $\mathrm{N}$ terminus (segment II). In addition, the peptide-spotting method for epitope mapping revealed that several peptides recognized by $15 \mathrm{~B} 3$ do not contain a YYR motif, whereas several peptides not recognized by 15B3 do contain YYR. The data, as presented ${ }^{2}$, indicate that YYR is not the 15B3 epitope.

The usefulness of the YYR epitope in prion immunotherapy or immunoprophylaxis remains open until confirmed by exper- imental tests, as do its potential diagnostic applications.

\section{COMPETING INTERESTS STATEMENT}

The authors declare competing financial interests (see the Nature Medicine website for details).

Eustache Paramithiotis ${ }^{1}$, Marc Pinard ${ }^{1}$,

Trebor Lawton ${ }^{2}$, Sylvie LaBoissiere ${ }^{I}$, Valerie L Leathers ${ }^{2}$, Wen-Quan Zou ${ }^{3}$, Lisa A Estey ${ }^{2}$, Julie Lamontagne ${ }^{1}$, Marty T Lehto ${ }^{3}$,Leslie H Kondejewski ${ }^{1}$ Gregory P Francoeur ${ }^{2}$, Maria Papadopoulos ${ }^{1}$, Ashkan Haghighat ${ }^{1}$, Stephen J Spatz ${ }^{2}$, Mark Head ${ }^{4}$, Robert Will ${ }^{4}$, James Ironside ${ }^{4}$, Katherine O'Rourke ${ }^{5}$, Quentin Tonelli, Harry C Ledebur ${ }^{1}$, Avi Chakrabartty ${ }^{6}$ \& Neil R Cashman ${ }^{1,3,6,7}$

${ }^{I}$ Caprion Pharmaceuticals, 7150 AlexanderFleming, St-Laurent, Quebec H4S 2C8, Canada.
${ }^{2}$ IDEXX Laboratories, 1 IDEXX Drive, Westbrook, Maine 04092, USA. ${ }^{3}$ Centre for Research in Neurodegenerative Diseases, 6 Queen's Park Crescent West, University of Toronto, Toronto, Ontario M5S 3H2, Canada. ${ }^{4}$ The National Creutzfeldt-Jakob Disease Surveillance Unit, Western General Hospital, Crewe Road, Edinburgh EH4 $2 X U, U K .{ }^{5} U S D A-A R S-A D R U$, 3003 ADBF, Washington State University, Pullman, Washington 99164-6630, USA. ${ }^{6}$ Department of Medical Biophysics, University of Toronto, Ontario Cancer Institute, 610 University Avenue, Toronto, Ontario M5G 2M9, Canada. ${ }^{7}$ Sunnybrook \& Women's College Health Sciences Centre, University of Toronto, 2075 Bayview Avenue, Toronto, Ontario M4N 3M5, Canada.

1. Paramithiotis, E. et al. Nat. Med. 9, 893-899 (2003).

2. Korth, C. et al. Nature 390, 74-77 (1997) 